\title{
Bacterial Production in Guanabara Bay (Rio de Janeiro, Brazil) Evaluated by ${ }^{3} \mathrm{H}$-Leucine Incorporation
}

\author{
Alessandra M. Gonzalez; Rodolfo Paranhos* ; Luciana Andrade and Jean L. Valentin \\ Departamento de Biologia Marinha, Instituto de Biologia; UFRJ, Prédio do CCS, Cidade Universitária, Rio de \\ Janeiro, RJ, 21944-970, Brazil.
}

\begin{abstract}
The aim of this work was to evaluate the necessary ${ }^{3} \mathrm{H}$-leucine concentration to estimate bacterial production in Guanabara Bay through saturation curves. A second aim was to collect preliminary data of bacterial production in two distinct sites corresponding to different water qualities: Urca inlet and Governador Island. Saturation curves were made with water samples taken at the main circulation channel of the bay, Paquetá Island, and the two sites mentioned before. The ${ }^{3}$ H-leucine curves showed similar pattern for all studied areas, indicating the ideal isotope concentration to be $10 \mathrm{nM}$. Bacterial biomass production ranged from 0.40 to $4.53 \mu \mathrm{gC} \mathrm{L}^{-1} \mathrm{~h}^{-1}$ in Urca and from 3.86 to $73.72 \mu \mathrm{gC} \mathrm{L} \mathrm{L}^{-1} \mathrm{~h}^{-1}$ in Governador Island indicating the relationship between nutrients and organic matter supply and bacterial productivity. This work is an important reference for studies on trophodynamics, biogeochemical cycles and modelling in Guanabara Bay.
\end{abstract}

Key words: bacterioplankton, activity measurement, heterothrophic production, estuary, water pollution, eutrophication.

\section{INTRODUCTION}

The true role of heterotrophic bacteria in the dynamics of aquatic ecosystems has been better understood in the last decades due to a lot of work on measurements of bacterial biomass and production (Cole et al., 1988; Servais, 1992; Aas et al, 1996; Sommaruga et al., 1997; Hoppe et al., 1998). Heterotrophic bacteria act degrading organic matter making inorganic nutrients available for the environment (Azam \& Cho, 1987) to be mainly used by phytoplanktonic cells in photosynthesis process. This nutrient regeneration allows the continuity of primary production in the euphotic zone even in the absence of new inputs of enriched water.

Besides this decomposing role, bacteria are important in the food web in aquatic ecosystems (Pomeroy, 1974). They are capable of incorporating dissolved organic matter in their cells converting it into particulate organic matter. The consumption of bacterial cells by protists and these by the microzooplankton make a paralallel flux of energy to the classic food web. This is the so called microbial loop (Azam et al., 1983). A high amount of organic matter that would not be available for the higher trophic levels due to its small dimensions become now integrated in the food web by the bacterial biomass production. This concept has greatly changed the way to look at bacteria.

The knowledge of the bacterial populations as an important parameter for the study of microbial ecology brought about various approaches to measure the bacterioplankton density, activity, biomass and production in aquatic environments (Bowden, 1977; Sorokin \& Lyutsarev, 1978; Porter \& Feig, 1980; Furham \& Azam, 1982; Azam et al., 1983; Amann et al., 1995). Between these, the incorporation of ${ }^{3} \mathrm{H}$-leucine proposed by Kirchman et al. (1985) is used to estimate bacterial activity by means of their protein synthesis. As the protein synthesis is related to the compounds absorbed from the environment, the bacterial production rates also varies with the availability of nutrients and organic matter, thus leading to higher bacterial production rates in very eutrophicated ecosystems such as Guanabara Bay in Brazil.

Guanabara Bay $\left(22^{\circ} 57^{\prime}\right.$ and $22^{\circ} 41^{\prime} \mathrm{S}$; $43^{\circ} 02^{\prime}$ and $43^{\circ} 16^{\prime} \mathrm{W}$ ) is located in a humid subtropical region surrounded by the Rio de Janeiro city (Figure 1). Its

*Author for correspondence 
total water volume is estimated as $2 \times 10^{9} \mathrm{~m}^{3}$ covering an area of $381 \mathrm{~km}^{2}$ (FEEMA, 1990). The bay has 42 islands, 53 beaches and 4000 $\mathrm{km}^{2}$ of watershed and tides are semi-diurnal with a maximum height of $1.4 \mathrm{~m}$ (BRASIL, 1976). Guanabara Bay has a status of environmental degradation due to eutrophication. (Hagler \& Hagler, 1981; Paranhos et al., 1995; Contador \& Paranhos, 1996; Paranhos et al., 1998). A population in excess of 10 million people discharges 470 tons of BOD daily with 5.5 tons of garbage. All domestic sewage is disposed virtually untreated into watershed and then into the bay. Industrial activities produce about 150 tons of sewage per day. The high availability of nutrients and organic matter (Lavrado et al., 1991) allows the proliferation of heterotrophic bacterial and phytoplankton blooms (Villac, 1990; Valentin et al., 1999).

In the present work we used the method of incorporation of ${ }^{3} \mathrm{H}$-leucine (Simon \& Azam, 1989; Kirchman, 1993) to estimate heterotrophic bacterial carbon production in Guanabara Bay. First saturation curves were made at different sites of Guanabara Bay with different degrees of pollution to establish the adequate concentration of ${ }^{3} \mathrm{H}$-leucine to be used. Then preliminary data on bacterial production were also obtained.

\section{MATERIAL AND METHODS}

Study site: Based on previous studies (Mayr et al., 1989; FEEMA, 1990; Villac et al., 1991; Contador \& Paranhos, 1996), four different sites were sampled to obtain ${ }^{3} \mathrm{H}$-leucine saturation curves: Urca inlet (1), Central Channel (2), Paquetá island (3) and Governador island (4). These sites are very different in terms of environmental quality and represent an eutrophication gradient from marine to continental waters. For saturation curves samples were collected on different days during 1998. Bacterial production was evaluated only at sites 1 and 4, from July to October 1998, making a total of 8 sampling dates.

Sampling: Water samples were taken with a cleaned Van Dorn bottle at $0.5 \mathrm{~m}$ of depth. Temperature was determined in the field with calibrated thermometers. Sub samples were first drained into a $300 \mathrm{ml}$ BOD flask for dissolved oxygen analysis, fixed immediately with manganese and iodide solutions and kept in the dark until processing in the laboratory (no longer than 1 h). Water samples were then stored in a $1 \mathrm{~L}$ amber stoppered glass flasks in the dark on ice for no longer than $1 \mathrm{~h}$. In the laboratory, samples were analysed for salinity, nutrients and chlorophyll a. Sub samples for bacterial production were collected at the surface water with sterile flasks and stored in the dark on ice (no longer than $1 \mathrm{~h}$ ) until further analysis.

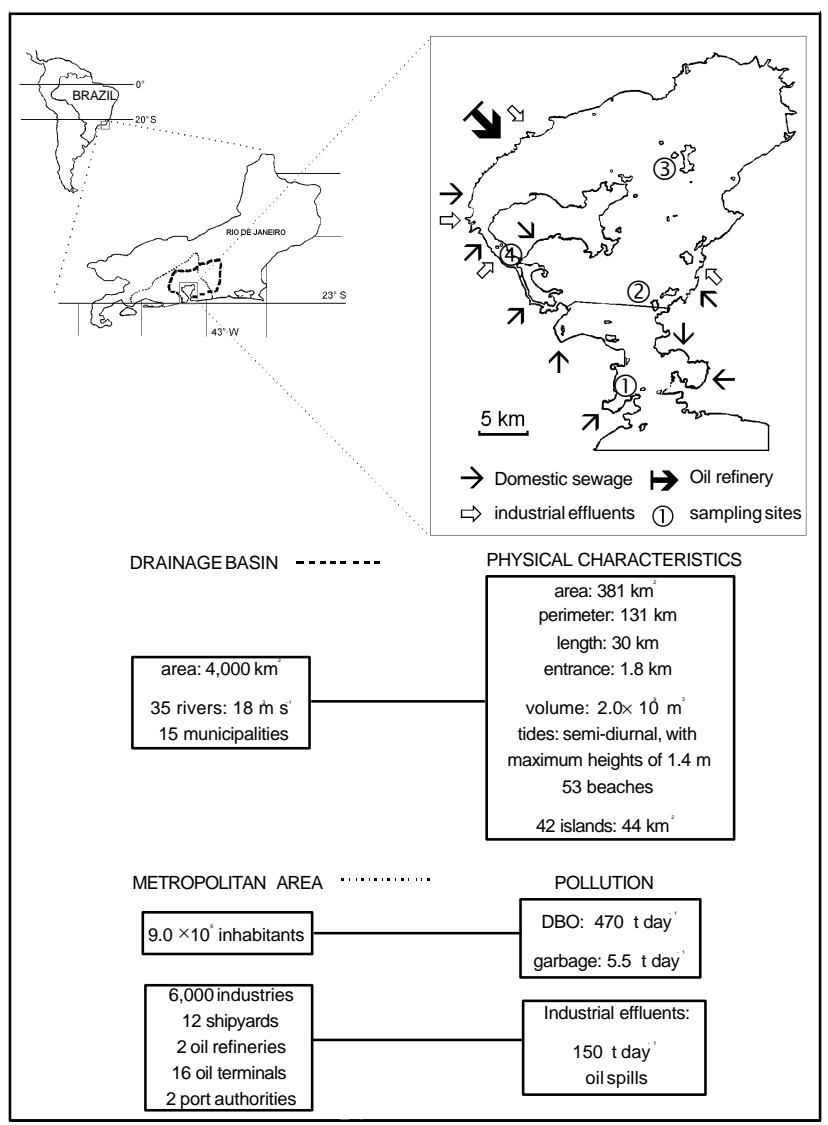

Figure 1 - Location of Guanabara Bay, its drainage basin, metropolitan area of Rio de Janeiro, and the sampling sites: Urca inlet (1), Central Channel (2), Paquetá Island (3) and Governador island (4). Pollution data from FEEMA (1990).

Bacterial production: Analysis followed the method of Kirchman et al. (1985) modified for microcentrifuge, instead of filtration, by Smith \& Azam (1992), and thus producing a minimum of radioactive waste. Triplicates of $1.7 \mathrm{~mL}$ of water sample were incubated with ${ }^{3} \mathrm{H}$-leucine (Amersham TRK 510, specific activity of $\left.171 \mathrm{mCi} \mathrm{nmol}^{-1}\right)$ at the concentrations of $10 \mathrm{nM}$ in $2 \mathrm{~mL}$ screwcap 
eppendorf tubes. One tube was amended with 90 $\mu \mathrm{L} 100 \%$ ice-cold trichloroacetic acid (TCA) as a killed control for abiotic uptake into the macromolecular fraction. Tubes were shaken on a vortex and incubated in the dark for $30 \mathrm{~min}$. Incubations were stopped by the addition of 90 $\mu \mathrm{L}$ of $100 \%$ ice-cold TCA. The tubes were again shaken on a vortex, centrifuged at $13000 \mathrm{rpm}$ under $20^{\circ} \mathrm{C}$ (Haraeus Biofuge fresco) for $10 \mathrm{~min}$ and the supernatant was carefully aspired under vacuum. Pellets were washed with $1.9 \mathrm{~mL}$ of $5 \%$ ice-cold TCA and with $1.7 \mathrm{~mL}$ of $80 \%$ ice-cold ethanol, centrifuged and dried as before. A volume of $0.5 \mathrm{~mL}$ of liquid scintillation cocktail (1.0 g of POPOP [Sigma P-3754], $7.0 \mathrm{~g}$ of POP [Sigma D-4630], 1.0 L of toluene) was added and samples were counted in a Beckman LS 6000 SC liquid scintillation counter, with internal calibration and quench correction. Rates of leucine incorporation were determined by subtracting the DPM determined in the TCAkilled control, and then by converting DPM to moles of leucine incorporated per hour. Bacterial carbon production was calculated using the protein/carbon correction factor of 0,86 (Simon \& Azam, 1989). Bacterial production on field samples was carried out as described before, using ${ }^{3} \mathrm{H}$-leucine at $10 \mathrm{nM}$.

Chemical analysis:, triplicate samples were analysed in the laboratory. Salinity was measured with a salinometer calibrated against Standard Sea Water and dissolved oxygen by Winkler-azide (both CNEXO, 1983). Reactive orthophosphate was done by the molybdenum blue method (Grasshoff et al., 1983). Ammoniac nitrogen $\left(\mathrm{N}-\mathrm{NH}_{3}+\mathrm{N}-\mathrm{NH}_{4}{ }^{+}\right.$, hereafter refereed to as ammonia) was determined by indophenol (Parsons et al., 1984). Nitrite was done by diazotation method (Grasshoff et al., 1983). Nitrate was determined by reduction in a $\mathrm{Cd}-\mathrm{Cu}$ column followed by diazotation (Grasshoff et al., 1983). Chlorophyll a analysis was performed by vacuum filtration through cellulose membrane filters (Millipore ${ }^{\circledR}$ HAWP $0.45 \mu \mathrm{m}$ ), extracted with $90 \%$ acetone. Spectrophotometer readings and calculations followed Parsons et al. (1984). Practical Salinity Units were used
(UNESCO, 1981), thereafter refereed as salinity (Symbol S). Correlation between bacterial production and physical and chemical parameters was determined by Spearman rank correlation index (Zar, 1984).

\section{RESULTS AND DISCUSSION}

Methodology optimisation: Bacterial carbon production as a measure of heterotrophic participation in aquatic environments can be estimated by the incorporation of radiolabelled leucine. The significance of the method lies on protein synthesis (Kirchman, 1993). Compared with other methods as ${ }^{3} \mathrm{H}$-thymidine, advantages are that leucine is essentially associated with proteins, representing a constant fraction of bacterial protein and it is not transformed into other amino acids. On the other hand, a disadvantage is that leucine can be sinthetized from other compounds which would lead to the dilution of radiolabelled leucine. The use of high enough concentrations of ${ }^{3} \mathrm{H}$-leucine would maximise incorporation of labelled leucine and repress the de novo synthesis of intracellular leucine (Simon \& Azam, 1989; Kirchman, 1993). But if the concentrations are excessive, ${ }^{3} \mathrm{H}$-leucine can be also incorporated by phytoplankton for example (Kirchman, 1993), as a source of nitrogen for biomass production. Thus, a recurrent problem in the use of radiolabelled nucleotides to estimate bacterial production is determining their saturation concentration (Törnblom \& Sondergaard, 1999).

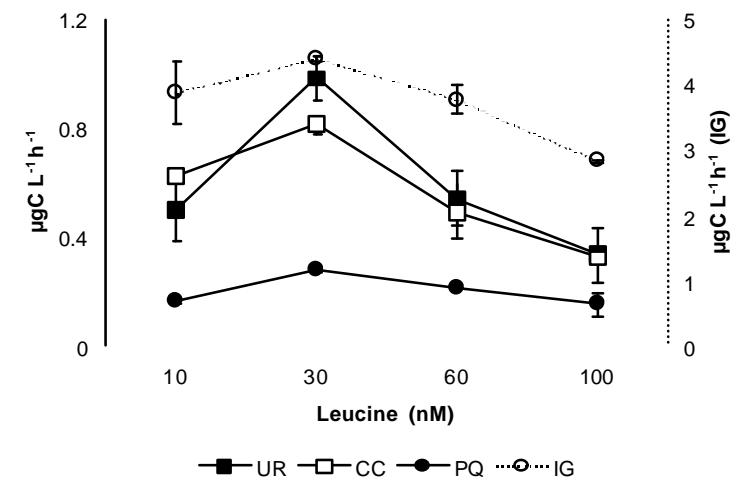

Figure 2 - Saturation curves of ${ }^{3} \mathrm{H}$-leucine for Urca inlet (UR), Central Channel (CC), Paquetá Island (PQ), and Governador island (IG, values at right axis), $n=3$.

The degradation process in Guanabara Bay is not uniform, existing different conditions of water 
quality (Mayr et al., 1989; Paranhos et al., 1998). Riemann \& Azam (1992) showed that ${ }^{3} \mathrm{H}$-leucine had a high extracellular dilution in eutrophicated environments, and the concentration used to estimate bacterial production varied with different degrees of pollution. The present study tested the concentrations of $10,30,60$ and $100 \mathrm{nM}$ in 4 areas of different pollution degrees.

Results showed that the best-labelled amino acid concentration ranged from 10 to $30 \mathrm{nM}$ in all the 4 areas studied (Figure 2). The average error in this technique ranged from 3 to $12 \%$. The saturation concentration of $10 \mathrm{nM}$ was then chosen and was in agreement with Simon \& Azam (1989) who found $10 \mathrm{nM}$ to be the ideal concentration to estimate bacterial production in the south of California. The concentration of 10 $\mathrm{nM}$ has been used for bacterial production estimations in many aquatic ecosystems (Hoch \& Kirchman, 1993; Turley \& Mackie, 1994; Pomeroy et al., 1995; Murrell et al., 1999).

Samples from Guanabara Bay incubated with 10 $\mathrm{nM}$ of ${ }^{3} \mathrm{H}$-leucine showed medium values of bacterial carbon production expressed in $\mu \mathrm{gC} \mathrm{L}^{-1}$ $\mathrm{h}^{-1}$ to be $0.50 \pm 0.12(23 \%)$ for Urca Inlet, $0.62 \pm$ $0.01(1 \%)$ for the central Channel, $0.16 \pm 0.01(7 \%)$ for Paquetá Island and $3.86 \pm 0.48(12 \%)$ for Governador Island. With the exception of Paquetá Island, the results followed an increasing gradient of pollution and agreed with those of Pomeroy et al. (1995). The authors worked in many stations in the Gulf of Mexico and found bacterial production to vary from 0.03 to $1.17 \mu \mathrm{gC} \mathrm{L} \mathrm{L}^{-1} \mathrm{~h}^{-1}$ respectively from the less to the most eutrophicated region.

The low levels of bacterial production in Urca Inlet and Central Channel are due to a better water quality condition, measured by low nutrients and dissolved organic matter concentration. This is justified by the influence of coastal waters from Atlantic Ocean which enter the bay and pass through these two sampling points (Mayr et al., 1989; Contador \& Paranhos, 1996). The opposite pattern was observed in Governador Island, a more polluted area due to the high quantities of organic matter disposed (Mayr et al., 1989) where higher levels of bacterial production were observed. The low bacterial production in Paquetá Island was in agreement with the prevailing coastal water influence at this site despite its inner bay loccation.

Table 1 - Results obtained from Urca inlet (UR), Central Channel (CC), Paquetá island (PQ) and Governador island (IG) for the following data: bacterial production (saturation curves - 10nM); temperature (Temp); salinity (Sal); $\mathrm{pH}$; dissolved oxygen (DO); oxygen saturation (\% Sat DO); chlorophyll a $(\mathrm{Chl} \underline{\mathrm{a}})$; suspended particulate matter (SPM); orthophosphate $\left(\mathrm{P}_{-} \mathrm{PO}_{4}{ }^{3-}\right)$; total phosphorus (total-P); ammonium $\left(\mathrm{N}-\mathrm{NH}_{3} / \mathrm{NH}_{4}{ }^{+}\right)$; nitrite $\left(\mathrm{N}-\mathrm{NO}_{2}{ }^{-}\right)$and silicate $(\mathrm{Si}-$ $\mathrm{SiO}_{2}$ ).

\begin{tabular}{|c|c|c|c|c|c|c|c|c|c|c|c|c|c|}
\hline & $\begin{array}{l}\text { Bacterial } \\
\text { production } \\
\text { at } 10 \mathrm{nM} \\
\left(\mu \mathrm{gC} \mathrm{L}_{1}^{-1} \mathrm{~h}^{-}\right.\end{array}$ & $\begin{array}{l}\text { Temp } \\
\left({ }^{\circ} \mathrm{C}\right)\end{array}$ & $\begin{array}{l}\text { Sal } \\
\text { (S) }\end{array}$ & $\mathrm{pH}$ & $\begin{array}{c}\text { DO } \\
\left(\mathrm{mL} \cdot \mathrm{L}^{-1}\right)\end{array}$ & $\begin{array}{c}\% \text { Sat } \\
\text { DO }\end{array}$ & $\begin{array}{c}\text { Chl } \underline{\mathrm{a}} \\
\left(\mu \mathrm{g} . \mathrm{L}^{-1}\right)\end{array}$ & $\begin{array}{c}\text { SPM } \\
\left(\mathrm{mg} \cdot \mathrm{L}^{-1}\right)\end{array}$ & $\begin{array}{c}\mathrm{P}-\mathrm{PO}_{4}{ }^{3-} \\
(\mu \mathrm{M})\end{array}$ & $\begin{array}{l}\text { Total-P } \\
(\mu \mathrm{M})\end{array}$ & $\begin{array}{c}\mathrm{N}- \\
\mathrm{NH}_{3} / \mathrm{NH}_{4}{ }^{+} \\
(\mu \mathrm{M})\end{array}$ & $\begin{array}{c}\mathrm{N}-\mathrm{NO}_{2}{ }^{-} \\
(\mu \mathrm{M})\end{array}$ & $\begin{array}{c}\mathrm{Si}- \\
\mathrm{SiO}_{2} \\
(\mu \mathrm{M})\end{array}$ \\
\hline $\begin{array}{c}\text { UR } \\
(16 \text { Oct })\end{array}$ & 0.50 & 24.50 & 30.43 & 8.34 & 4.27 & 85.08 & 26.03 & 18.80 & 0.86 & 1.96 & 8.87 & 1.49 & 16.92 \\
\hline $\begin{array}{c}\text { CC } \\
(24 \\
\text { Aug) }\end{array}$ & 0.62 & 27.00 & 31.99 & 8.28 & 4.30 & 88.40 & 24.77 & 20.20 & 1.15 & 2.30 & 35.88 & 1.03 & 29.59 \\
\hline $\begin{array}{c}\text { PQ } \\
(24 \\
\text { Aug) }\end{array}$ & 0.16 & 25.00 & 32.24 & 8.29 & 3.20 & 64.59 & 18.41 & 16.60 & 0.91 & 2.12 & 22.57 & 0.85 & 22.94 \\
\hline $\begin{array}{c}\text { IG } \\
(30 \mathrm{Jul})\end{array}$ & 3.86 & 23.00 & 29.98 & 7.85 & 0.20 & 3.90 & 73.95 & 14.79 & 6.97 & 9.20 & 100.90 & 3.29 & 85.88 \\
\hline
\end{tabular}


Table 2 - Data obtained from Urca inlet and Governador island during the year of 1998: average (avg), standard deviation (SD), relative standard deviation $(\mathrm{CV} \%)$, total number $(\mathrm{N})$ and minimum and maximum values for: bacterial production ( $\mu \mathrm{gC} \mathrm{L} \mathrm{L}^{-1} \mathrm{~h}^{-1}$ ); temperature (Temp); salinity (Sal); pH; dissolved oxygen (DO); oxygen saturation (\% Sat DO); chlorophyll $\underline{\text { a }}(\mathrm{Chl} \underline{\mathrm{a}})$ suspended particulate matter (SPM); orthophosphate $\left(\mathrm{P}-\mathrm{PO}_{4}{ }^{3-}\right)$; total phosphorus (P-total); ammonium $\left(\mathrm{N}-\mathrm{NH}_{3} / \mathrm{NH}_{4}{ }^{+}\right)$; nitrite $\left(\mathrm{N}-\mathrm{NO}_{2}{ }^{-}\right)$; and silicate $\left(\mathrm{Si}-\mathrm{SiO}_{2}\right)$.

\begin{tabular}{|c|c|c|c|c|c|c|c|c|c|c|c|c|c|}
\hline Urca & $\begin{array}{c}\text { Bacterial } \\
\text { production } \\
\left(\mu \mathrm{gC} \mathrm{L}^{-1} \mathrm{~h}^{-1}\right)\end{array}$ & $\begin{array}{c}\text { Temp } \\
\left({ }^{\circ} \mathrm{C}\right)\end{array}$ & $\begin{array}{l}\text { Sal } \\
\text { (S) }\end{array}$ & $\mathrm{pH}$ & $\begin{array}{c}\mathrm{OD} \\
\left(\mathrm{mL} \cdot \mathrm{L}^{-1}\right)\end{array}$ & $\begin{array}{c}\text { \% Sat. } \\
\text { DO }\end{array}$ & $\begin{array}{c}\text { Chl } \frac{\mathrm{a}}{\left(\mu \mathrm{g} . \mathrm{L}^{-1}\right)} \\
\end{array}$ & $\begin{array}{c}\text { SPM } \\
\left(\mathrm{mg} \cdot \mathrm{L}^{-1}\right)\end{array}$ & $\begin{array}{c}{\mathrm{P}-\mathrm{PO} 4^{3-}}_{(\mu \mathrm{M})}\end{array}$ & $\begin{array}{c}\text { Total-P } \\
(\mu \mathrm{M})\end{array}$ & $\begin{array}{c}\mathrm{N}- \\
\mathrm{NH}_{3} / \\
\mathrm{NH} \\
(\mu \mathrm{M})\end{array}$ & 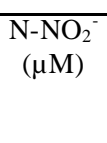 & $\begin{array}{c}\mathrm{Si}- \\
\mathrm{SiO}_{2} \\
(\mu \mathrm{M})\end{array}$ \\
\hline$\overline{\overline{A v g}}$ & $\overline{1.81}$ & 23.63 & 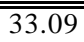 & 8.20 & $\overline{2.49}$ & 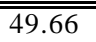 & $\bar{~} 12.34$ & $\overline{19.56}$ & $\overline{1.34}$ & $\overline{2.08}$ & 13.95 & 1.49 & 20.51 \\
\hline $\mathrm{SD}$ & 1. & 0.64 & 1.28 & 0.08 & 1.25 & 24.99 & 7.82 & 5.05 & 0.36 & 0. & 3.96 & 0.19 & 6.43 \\
\hline CV\% & 85.65 & 2.71 & 3.87 & 1.01 & 50.24 & 50.32 & 63.39 & 25.80 & 26.67 & 35.57 & 28.40 & 13.11 & 31.37 \\
\hline $\mathrm{N}$ & 7 & 8 & 8 & 7 & 8 & 8 & 8 & 7 & 8 & 8 & 8 & 8 & 8 \\
\hline Minimum & 0.40 & 22.50 & 30.43 & 8.10 & 0.82 & 16.36 & 3.89 & 12.30 & 0.86 & 0.72 & 8.43 & 1.20 & 12.32 \\
\hline Maximum & 4.53 & 24.50 & 34.35 & 8.34 & 4.27 & 85.08 & 26.03 & 24.40 & 1.94 & 3.02 & 20.62 & 1.76 & 32.31 \\
\hline
\end{tabular}

\begin{tabular}{|c|c|c|c|c|c|c|c|c|c|c|c|c|c|}
\hline $\begin{array}{l}\text { Governad } \\
\text { or Island }\end{array}$ & $\begin{array}{c}\text { Bacterial } \\
\text { production } \\
\left(\mu \mathrm{gC} \mathrm{L} \mathrm{L}^{-1} \mathrm{~h}^{-1}\right)\end{array}$ & $\begin{array}{c}\text { Temp } \\
\left({ }^{\circ} \mathrm{C}\right)\end{array}$ & $\begin{array}{l}\text { Sal } \\
(\mathrm{S})\end{array}$ & $\overline{\mathrm{pH}}$ & $\begin{array}{c}\mathrm{DO} \\
\left(\mathrm{mL} . \mathrm{L}^{-}\right. \\
1)\end{array}$ & $\begin{array}{c}\% \text { Sat } \\
\text { DO }\end{array}$ & $\begin{array}{c}\text { Chl } \underline{\mathrm{a}} \\
(\mu \mathrm{g} . \mathrm{L} \\
\mathrm{T})\end{array}$ & $\begin{array}{c}\text { SPM } \\
\left(\mathrm{mg}^{\prime} \mathrm{L}^{-1}\right)\end{array}$ & $\begin{array}{c}\mathrm{P}^{-\mathrm{PO} 4^{3-}} \\
(\mu \mathrm{M})\end{array}$ & $\begin{array}{l}\text { P-total } \\
(\mu \mathrm{M})\end{array}$ & $\begin{array}{c}\mathrm{N}- \\
\mathrm{NH}_{3} / \mathrm{NH} \\
(\mu \mathrm{M})\end{array}$ & 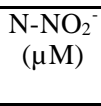 & $\begin{array}{c}\mathrm{SiO}_{2} \\
(\mu \mathrm{M})\end{array}$ \\
\hline$\overline{\overline{A v g}}$ & 16.98 & 25.19 & 25.67 & 8.05 & 1.61 & 31.78 & 170.35 & 42.10 & 8.12 & 111.68 & 127.46 & 2.19 & 58.19 \\
\hline SD & 23.09 & 1.19 & 3.71 & 0.29 & 1.61 & 31.44 & 179.72 & 17.56 & 4.32 & 3.61 & 25.37 & 1.22 & 39.36 \\
\hline $\mathrm{CV} \%$ & 135.98 & 4.74 & 14.47 & 3.63 & 100.06 & 98.93 & 105.50 & 41.70 & 53.24 & 30.91 & 19.91 & 55.42 & 67.63 \\
\hline $\mathrm{N}$ & 8 & 8 & 8 & 7 & 8 & 8 & 8 & 7 & 8 & 8 & 8 & 8 & 8 \\
\hline Minimum & 3.86 & 23.00 & 20.11 & 7.66 & 0.00 & 0,00 & 9.51 & 14.79 & 0.86 & 5.27 & 87.11 & 0.42 & 9.16 \\
\hline Maximum & 73.72 & 27.00 & 30.35 & 8.45 & 4.35 & 83.38 & 483.54 & 70.80 & 13.20 & 15.48 & 162.70 & 3.69 & 102.35 \\
\hline
\end{tabular}

Field results: Using $10 \mathrm{nM}$ of ${ }^{3} \mathrm{H}$-leucine bacterial carbon production was estimated for Urca Inlet and Governador Island, which represent the less and the most eutrophicated areas of the whole bay according to Mayr et al. (1989). During the period of study (July to October, 1998) bacterial production rates varied from 0.40 to $4.53 \mu \mathrm{gC} \mathrm{L}^{-1} \mathrm{~h}^{-1}$ in Urca Inlet and from 3.86 to $73.72 \mu \mathrm{gC} \mathrm{L^{-1 }} \mathrm{h}^{-1}$ in Governador Island (Table 1). The results agreed with those of Cole et al. (1988) who found a range of 0.40 to $153 \mu \mathrm{gC} \mathrm{L} \mathrm{L}^{-1} \mathrm{~h}^{-1}$ for the pelagic heterotrophic bacteria biomass production in 24 freshwater and 30 marine systems. The results were also in agreement with those of Hoppe et al. (1998) for three regions of Schlei Fjord on the north of Germany. The authors found values of 0.0013 and $0.22 \mu \mathrm{gC} \mathrm{L}^{-1} \mathrm{~h}^{-1}$, which varied with the eutrophication degree in the fjord.

Physical and chemical data obtained for the two sampling sites confirmed the different conditions of eutrophication (Table 2). Lower temperature $\left(23.63^{\circ} \mathrm{C}\right)$ and higher salinity $(33.09$ S) values for Urca Inlet showed the influence of marine waters. On the other hand, higher temperature $\left(25.19^{\circ} \mathrm{C}\right)$ and lower salinity $(25.67)$ values for Governador Island indicated a more stagnated water area with a higher degree of pollution (Mayr et al., 1989; Lavrado et al.,
1991). Values of dissolved oxygen were also higher for Urca Inlet $\left(2.49 \mathrm{~mL} \cdot \mathrm{L}^{-1}\right)$. The values of dissolved oxygen for Governador Island showed a high variation going from an state of anoxia to a maximum of $4.35 \mathrm{~mL} \cdot \mathrm{L}^{-1}$. But oxygen saturation found for this site was lower (32\%) than the one for Urca Inlet $(50 \%)$. This was probably due to the amount of organic matter found in Governador Island, which was decomposed by bacteria consuming the oxygen in the water. The high variability of dissolved oxygen is a characteristic of eutrophic environments with high phytoplanktonic production. This was confirmed by the high values of chlorophyll a concentration of $170 \mu \mathrm{g} . \mathrm{L}^{-1}$.

The high production of phytoplankton occurs due to of the availaibility of nutrients that enter the bay with the discharges of domestic efluents. All nutrient data (orthophosphate, total phosphorus, amomnia, nitrite and silicate) were higher in Governador Island (Table 2). The opposite was observed for Urca inlet, both for nutrients and chlorophyll a values (Table 2). Particulated suspended matter was also higher for Governador Island (42.10 mg.. $\mathrm{L}^{-1}$ ) when compared to Urca Inlet (19.56 mg. $\left.\mathrm{L}^{-1}\right)$. All these results indicated that the bacterial carbon production rates could be used as a biological parameter to monitor water quality changes in the bay.

Correlation between variables confirmed the pattern discribed above. For example, a very strong negative 
correlation between bacterial production and salinity was found $(-0.796, \mathrm{p}<0.01)$, confirming the bacterial dilution in oceanic waters. This justified the lower bacterial carbon production found for Urca inlet, Central Channel and Paquetá island when compared to Governador island. The positive correlation between bacterial production and chlorophyll $\underline{\mathrm{a}}(0.544$, $\mathrm{p}<0.05)$ suggested that the increase in bacterial biomass was related to the increase in primary production. This means that the organic matter produced by the phytoplankton could be used as an energy supply for protein synthesis by heterotrophic cells (Azam \& Cho, 1987). This correlation also indicated that both bacteria and phytoplankton increased mainly due to the availability of alloctone sources of nutrients (Hoch \& Kirchman, 1993; Pomeroy et al., 1995). This was confirmed by the positive correlation between bacterial production and chlorophyll $\underline{\mathrm{a}}$ with total phosphorus (0.843, $\mathrm{p}<0.01$ and $0.669, \mathrm{p}<0.01)$ and ammonium $(0.789, p<0.01$ and $0.735, p<0.01)$. The results obtained agreed with those of Cole et al. (1988) and Hoch \& Kirchman (1993) who found a strong correlation between bacterial biomass production, chlorophyll a and nutrients values.

\section{CONCLUSIONS}

The ${ }^{3} \mathrm{H}$-leucine saturation curves showed similar pattern for all the sampling sites indicating that a concentration of $10 \mathrm{nM}$ could be used for estimations of bacterial production in Guanabara Bay. The preliminary data found for estimations of bacterial production were in agreement with the water conditions found in Urca inlet and Governador island. The strong correlation between bacterial biomass production and the other pollution indicators suggested that the carbon produced by bacteria varied directly with the eutrophication pattern within the bay.

The measurement of heterotrophic bacterial production by ${ }^{3} \mathrm{H}$-leucine incorporation represents a new approach in the studies of the estuary of Guanabara Bay. It can now be used as valuable biological tool in monitoring and water quality recuperation programs. The technique is also an important reference for studies on trophodynamics, biogeochemical cycles and modelling in Guanabara Bay.

ACKNOWLEDGMENTS
We are grateful to PRONEX/MCT 0877/96; FUJB, CNPq and FAPERJ (E-26/171.265/97.APQ1) for financial support. We are also grateful to Grupamento de Salvamento Aéreo do Aeroporto Internacional do Rio de Janeiro (SAR.) and Escola Superior de Guerra for their important contributions during field activities. We thank the UFRJ Limnology Laboratory for their support in scintillation counts and Dr. Bias Faria for suggestions on manuscript.

\section{RESUMO}

O objetivo desse trabalho foi realizar curvas de saturação a fim de otimizar a concentração de ${ }^{3} \mathrm{H}$ leucina necessária para avaliar produção bacteriana na Baía de Guanabara. Objetivou-se ainda a aquisição de dados preliminares de produção bacteriana em dois locais distintos em termos de qualidade de água : enseada da Urca e Ilha do Governador. As amostras para as curvas foram obtidas na região do Canal Central e na Ilha de Paquetá, além dos dois locais de coleta citados acima. Seguiu-se a metodologia descrita por Kirchman et al. (1985) e modificada por Smith \& Azam (1992). As curvas de ${ }^{3} \mathrm{H}$-leucina mostraram um padrão semelhante para todas as áreas estudadas, indicando a concentração ótima de isótopo de 10 nM. A produção de biomassa bacteriana variou de 0,40 a $4,53 \mu \mathrm{gC} \mathrm{L} \mathrm{L}^{-1} \mathrm{~h}^{-1}$ na Urca e de 3,86 a 73,72 $\mu \mathrm{gC} \mathrm{L^{-1 }} \mathrm{h}^{-1}$ na Ilha do Governador confirmando a relação entre a disponibilidade de nutrientes e matéria orgânica e o aumento da produtividade bacteriana. Essas análises poderão ser utilizadas para estudos sobre dinâmica trófica, ciclos biogeoquímicos além de iniciativas de modelagem na Baía de Guanabara.

\section{REFERENCES}

Aas, P.; Lyons, M. M.; Pledger, R.; Mitchell, D. L. \& Jeffrey, W. H. (1996), Inhibition of bacterial activities by solar radiation in nearshore waters and the Gulf of Mexico. Aquat. Microb. Ecol., 11, 229-238.

Amann, R. I.; Ludwig, W. \& Schleifer, K-H. (1995), Phylogenetic identification and in situ detection of individual microbial cells without cultivation. Microbiol. Rev., 59 (1), 143-169.

Azam, F.; Fenchel, T.; Field, J. G.; Gray, J. S.; MeyerReil, L. A. \& Thingstad, F. (1983), The ecological role 
of water-column microbes in the sea. Mar. Ecol. Prog. Ser., 10, 257-263.

Azam, F. \& Cho, B. C. (1987), Bacterial utilization of organic matter in the sea. In- Ecology of microbial communities, ed. M. Fletcher.; T.R.G. Gray \& J.G. Jones. Cambridge University Press, pp. 261-281.

Bowden, W. B. (1977), Comparison of two directcount techniques for enumerating aquatic bacteria. Appl. Environ. Microbiol., 33, 1229-1232.

BRASIL (1976), Roteiro da costa sul - Brasil, Rio de Janeiro. Ministério da Marinha, Diretoria de Hidrografia e Navegação, pp. 49-78.

CNEXO (1983), Manuel des Analyses Chimiques au Milieu Marin, CNEXO - BNDO Documentation, ed. Aminot, A. \& Chassieupied, M., France, 397 pp.

Cole, J. J.; Findlay, S. \& Pace, M. L. (1988), Bacterial production in fresh and saltwater ecosystems: a cross-system overview. Mar. Ecol. Prog. Ser., 43, 1-10.

Contador, L. \& Paranhos, R. (1996), Water quality trends in Urca inlet (Guanabara Bay, Brazil) from 1986 to 1992. Arq. Biol. Tecnol., 39 (3), 735-744.

FEEMA (1990), Projeto de recuperação gradual do ecossistema da Baía de Guanabara. Fundação Estadual de Engenharia do Meio Ambiente FEEMA, Rio de Janeiro, $2^{\circ}$ volume, 203 pp.

Fuhrman, J. A. \& Azam, F. (1982), Thymidine incorporation as a measure of heterotrophic bacterioplankton production in marine surface waters: evaluation and field results. Mar. Biol., 66, 109-120.

Grasshoff, K.; Erhardt, M. \& Kremling, K. (1983), Methods of seawater analysis, 2nd ed., Weinhein Verlag Chemie, pp. 125-139.

Hagler, A. N. \& Hagler, L. C. M. (1981), Yeasts from marine and estuarine waters with different levels of pollution in the state of Rio de Janeiro, Brazil. Appl. Environ. Microbiol., 41, 173-178.

Hoch, M. P. \& Kirchman, D. L. (1993), Seasonal and inter-annual variability in bacterial production and biomass in a temperate estuary. Mar. Ecol. Prog. Ser., 98, 283-295.

Hoppe, H. G.; Giesenhagen, H. C. \& Gocke, K. (1998), Changing patterns of bacterial substrate decomposition in a eutrophication gradient. Aquat. Microb. Ecol., 15, 1-13.

Kirchman, D. L. (1993), Leucine incorporation as a measure of biomass production by heterothrophic bacteria. In- Handbook of Methods in Aquatic Microbial Ecology, ed. P. F. Kemp; B. F. Sherr; E. B. Sherr \& J. J. Cole. Lewis Publishers, pp. 509517.

Kirchman, D.L.; K'nees, E. \& Hodson, R. (1985), Leucine incorporation and its potential as a measure of protein synthesis by bacteria in natural aquatic systems. Appl. Environ. Microbiol., 49, 599607.

Lavrado, H.; Mayr, L. M.; Carvalho, V. \& Paranhos, R. (1991), Evolution (1980-1990) of ammonia and dissolved oxygen in Guanabara Bay, RJ, Brazil. In: Proc. 7th Symp. On Coastal and Ocean Management Coastal Zone 7 (4), 3234-3245.

Mayr, L. M.; Tenenbaum, D. R.; Villac, M. C.; Paranhos, R.; Nogueira, C. R.; Bonecker, S. L. C. \& Bonecker, A. C. (1989), Hydrobiological characterization of Guanabara Bay. In Coastlines of Brazil. O. T. Maggon \& C. Neves. Am. Soc. Civil Engin., pp. 124-139.

Murrell, M. C.; Hollibaugh, J. T.; Silver, M. W. \& Wong, P. S. (1999), Bacterioplankton dynamics in northern San Francisco Bay: role of particle association and seasonal freswater flow. Limnol. Oceanogr., 44 (2), 295-308

Paranhos, R.; Nascimento, S. M. \& Mayr, L. M. (1995), On the faecal pollution in Guanabara Bay, Brazil. Fresenius Environ. Bull., 4, 352-357.

Paranhos, R.; Pereira, A. P. \& Mayr, L. M. (1998), Diel variability of water quality in a pollution gradient in a tropical polluted bay. Environ. Monit. Assess., 50, 131141.

Parsons, T. R.; Maita, Y. \& Lalli, C. M. (1984), A manual of chemical and biological methods for seawater analysis. Oxford, Pergamon Press, 173 pp.

Pomeroy, L. R. (1974), The ocean's food web, a changing paradigm. Bioscience, 24 (9), 499-504.

Pomeroy, L. R.; Sheldon, J. E.; Sheldon Jr., W. M. \& Peters, F. (1995), Limits to growth and respiration of bacterioplankton in the Gulf of Mexico. Mar. Ecol. Prog. Ser., 117, 259-268.

Porter, K. G. \& Feig, Y. S. (1980), The use of DAPI for identifying and counting aquatic microflora. Limnol. Oceanogr., 25, 943-948.

Riemann, B. \& Azam, F. (1992), Measurements of bacterial protein synthesis in eutrophic aquatic environments by means of leucine incorporation. Mar. Microb. Food Webs, 6 (2): 91-105.

Servais, P. (1992), Bacterial production measured by ${ }^{3} \mathrm{H}-$ thymidine and ${ }^{3} \mathrm{H}$-leucine incorporation in various aquatic ecosystems. Arch. Hydrobiol. Beih. Ergebn. Limonol., 37, 73-81.

Simon, M. \& Azam, F. (1989),. Protein content and protein synthesis rates of planktonic marine bacteria. Mar. Ecol. Prog. Ser., 51, 201-213.

Smith, D. C. \& Azam, F. (1992), A simple, economical method for measuring bacterial protein synthesis rates in seawater using ${ }^{3}$ H-leucine. Mar. Microb. Food Webs, $6(2), 107-114$.

Sommaruga, R.; Obernosterer, I.; Herndl, G. J. \& Psenner, R. (1997), Inhibitory effect of solar radiation on thymidine and leucine incorporation by freshwater and marine bacterioplankton. Appl. Environ. Microbiol., 63 (11), 4178-4184.

Sorokin, Y. I. \& Lyursarev, S. V. (1978), A comparative evaluation of two methods for determining the biomass 
of planktonic microflagellates. Oceanol. Acad. Sci. U. S. S. R,. 18, 232-236.

Törnblom, E. \& Sondergaard, M. (1999), Seasonal dynamics of bacterial biomass and production on eelgrass Zostera marina leaves. Mar. Ecol. Prog. Ser., 179, 231-240.

Turley, C. M. \& Mackie, P. J. (1994), Biogeochemical significance of attached and freeliving bacteria and the flux of particles in the NE Atlantic Ocean. Mar. Ecol. Prog. Ser., 115, 191203.

UNESCO (1981), Tenth report of the joint panel on oceanographic tables and standards. Unesco Tech. Pap. Mar. Sci. 36.

Valentin J; Tenenbaum, D. R.; Bonecker, A.; Bonecker, S.; Nogueira, C.; Paranhos, R. \& Villac, M. C. (1999), Caractéristiques hydrobiologiques de la Baie de Guanabara (Rio de Janeiro, Brésil). J. Rech. Oceanographique 24 (1):33-41.
Villac, M. C. (1990), O fitoplâncton como um instrumento de diagnose e monitoramento ambiental: estudo de caso da Baía de Guanabara (RJ, Brasil). Msc. Thesis, Instituto de Geociências, UFRJ, Rio de Janeiro, 193pp.

Villac, M. C.; Mayr, L. M.; Tenenbaun, D. R. \& Paranhos, R. (1991), Sampling strategies proposed to monitoring Guanabara Bay (Brazil). In: Proc. 7th Symp. On Coastal and Ocean Management - Coastal Zone 7 (2), 1168-1182.

Zar, J. H. (1984), Biostatistical Analysis. 2nd ed., Prentice-Hall, New Jersey, 469pp.

Received: August 23, 1999; Revised: November 26, 1999; Accepted: February 09, 2000. 